\title{
The Issue of Residential Mobility in the Congo; Case of the City of Brazzaville
}

\author{
Nzoussi Hilaire Kevin*, Li Jiang Feng, Koua Stephen Faller*, Mabiala Koyo Grace, \\ Mouele Mboungou Patrick Joe Stivell*, Naoueyama Corine Elsa \\ School of Public Administration, China University of Geosciences, Wuhan, China \\ *Corresponding author: nzoussik@yahoo.fr, Stephen_faller@yahoo.fr, mamamyalove@yahoo.fr
}

Received September 17, 2014; Revised September 29, 2014; Accepted October 08, 2014

\begin{abstract}
Urbanization is the developing process of cities. For over a decade, African cities in general have had a very high population growth. We have observed the same trend within the same time period in Brazzaville, the political capital. This is probably due to the Political and Economic stability particularly marked by urbanization and the boom of the oil industry. This significant population growth, especially not controlled results in jeopardizing all the urbanization planning and cause a lot problems. Cities have certainly some advantages because they are opened to the world, however, it is a big challenge for everyone to live and comply with cities 'constraints and requirements. Feeding, clothing and getting a decent accommodation are undoubtedly big issues the economically weak have to challenge. This article aims to study first the causes and consequences of residential mobility's in Brazzaville, then offers some possible solutions in order to reduce this problem. These are the main objectives assigned to this work.
\end{abstract}

Keywords: Problematic, residential mobility, Congo, city, Brazzaville

Cite This Article: Nzoussi Hilaire Kevin, Li Jiang Feng, Koua Stephen Faller, Mabiala Koyo Grace, Mouele Mboungou Patrick Joe Stivell, and Naoueyama Corine Elsa, "The Issue of Residential Mobility in the Congo; Case of the City of Brazzaville.” American Journal of Educational Research, vol. 2, no. 10 (2014): 906-910. doi: 10.12691/education-2-10-9.

\section{Introduction}

Most African cities are experiencing very high natural growth of their urban population. In Congo, this situation create migration movements towards urban centers (Anglade and al, 1988) This impressive urban growth having its roots in the rural exodus (Vennetier, 1990) declines considerably the living conditions of urban population areas. Feeding, transportation and housing questions are really nightmares for low class people having only a few and insufficient financial resources. Poor neighborhoods are most affected by these problems. These kinds of districts are called townships in South Africa, favelas in Brazil, the slums in other lands, and poor districts in Brazzaville. Several factors contribute to the residential mobility in the city of Brazzaville. These factors are social as well as economic. In this current article, the main purposes are to display the causes of residential mobility in Congo, the case of Brazzaville, to measure the consequences of this phenomenon and suggest some solutions to a better life quality of the populations.

\section{Study Area}

Brazzaville is the political capital of the Republic of Congo, and the country's first city. It is located on the right bank of the Congo River. Brazzaville was administratively divided into 7 districts until 2011 which are; Makélékélé, Bacongo, Poto- Poto, Ouenzé, Talangai, Moungali Mfilou and as shown in this figure (Figure 1).

But due to the spatial extension of the city and the exponential population growth, two other districts were born. These are Djiri and Madibou (fin2011) City with multiple functions. Brazzaville annually attracts many new urbanites coming from everywhere. It is located in the department of pool. It is bounded north and south by the department of the pool, on the east by the Congo River and to the west by the department of pool. The geographical coordinates of the city of Brazzaville; 4 degrees latitude 16 south, longitude 15 degrees 16 east. His current surface area of $263.9 \mathrm{~km}^{2}$ with a population of 1.373.382 inhabitants. (CNSEE, 2007), a population density of 5204inhabitants / $\mathrm{km}^{2}$.

\section{The Urban Fabric and Land Occupation in Brazzaville}

The urban fabric can be defined as how a city looks like in terms of spatial occupation. So it is the visual form of a city that allows differences to be made according to the type of spatial occupation and organisation (Motsara 1986). In Congo Brazzaville as in other cities of SSA countries housing quality highly reflects monthly income available to an individual. So, accommodation standing emphasizes unavoidably social division between rich, 
middle class and low class people. The homes are often built by the people themselves with their own efforts and available incomes. We often talk about unplanned urbanization. On the other hand, housing built by state authorities over large areas with a well-defined map are said to be planned. These houses are built by private and parastatal organizations such as CPPM (Company Protection and Property Management) IRC (Insurance and Reinsurance of Congo) NCE (National Company of Electricity) .... After independence in 1960, many homes were built, although others were inherited from colonization. Nowadays, with the revitalization of Chinese cooperation, several social housing is being built as shown in this figure below.

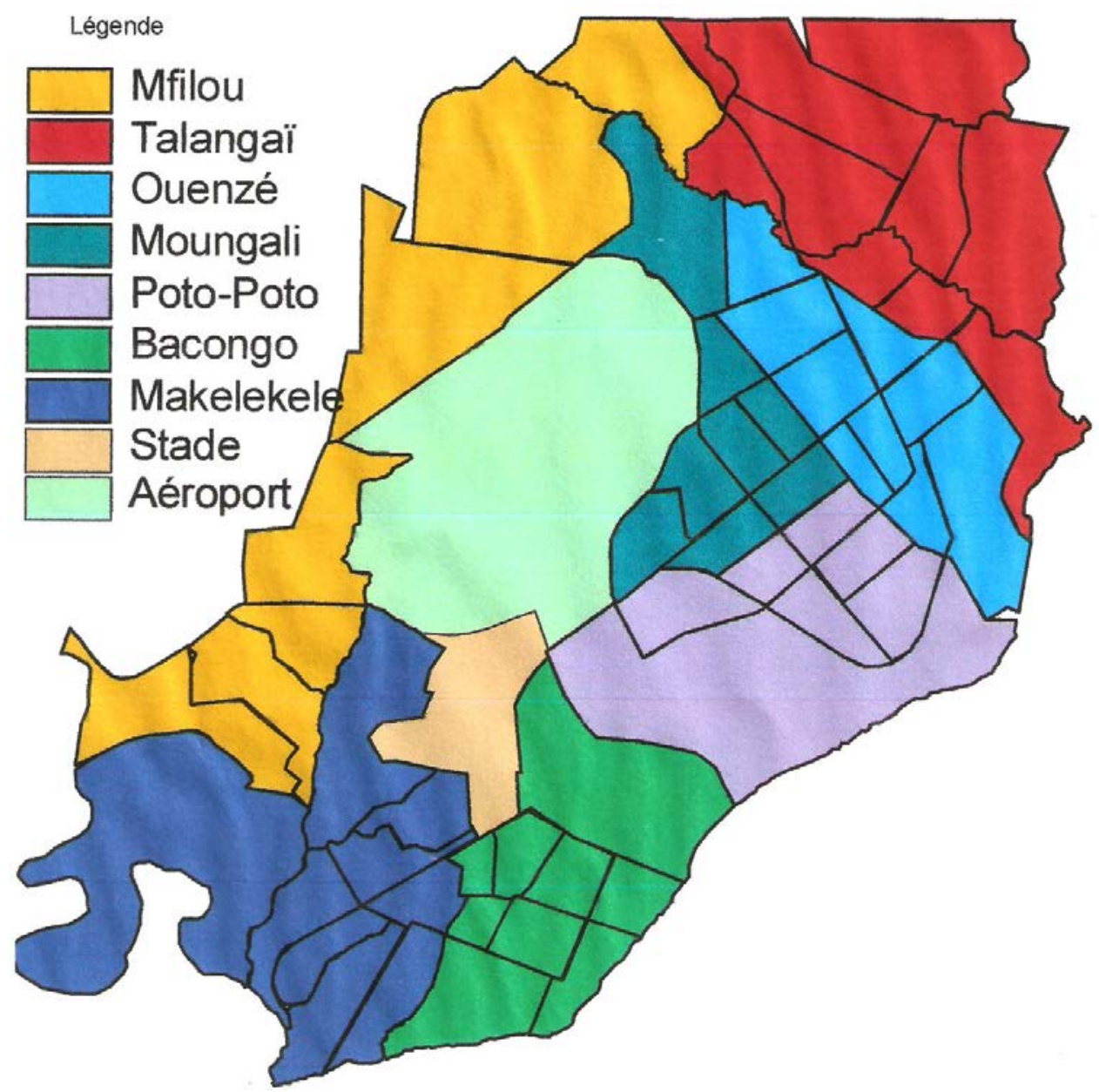

Figure 1. borough and districts of the city of Brazzaville

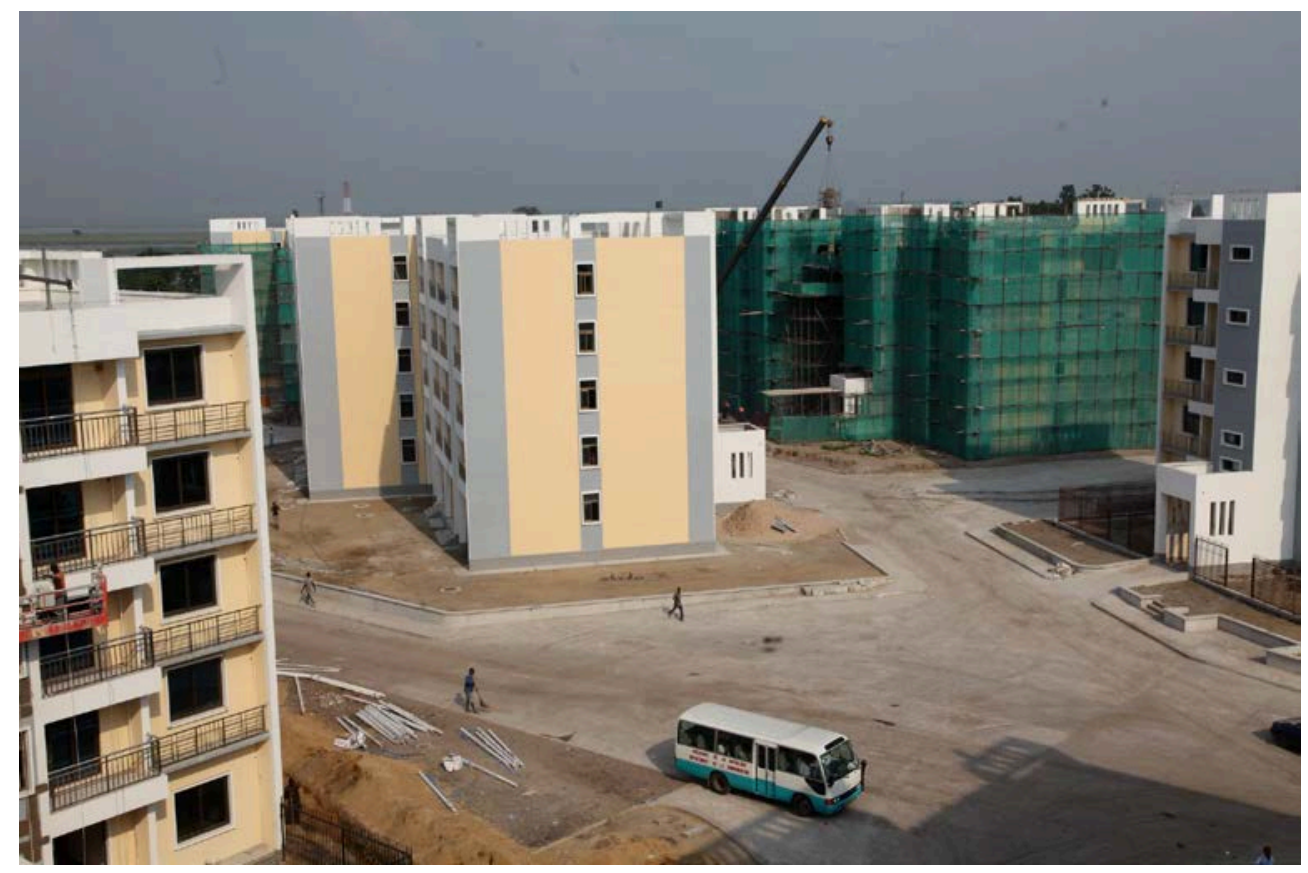

Figure 2. social housing construction M'Pila (Brazzaville) 
Indeed, the so-called planned housing habitats are often inhabited by wealthy men, dignitaries of power and some businessmen including diplomats in Brazzaville. Low income people can obviously not afford to have these kinds of accommodations and no one cares about them. So, those poor people have to resort to the suburbs that are marginalized areas lacking of urban infrastructures (Dureaud et al, 2000). The house types, the spatial occupation style of the building lands especially horizontal building bring about serious problems in Brazzaville. (Motsara 1986). Estimated to 122,000 inhabitants in 1961,420.000 in 1981, around 900000 in 1998 and 3.731 .382 in 2007 (Yekoka), population growth poses real problems not only of administration but also of space and population management. Land acquisition in Brazzaville is very difficult due to the cost of living, administrative texts and misunderstanding between the state authorities and landowners. For the record, around the year 1963, the land was nationalized throughout the territory of the Congo. In 1969, the land was declared property of the people with this famous formula of Marxist Leninists regimes "everything for the people, just for the people (Ibid). This led to a race of public space, and an anarchic occupation of lands. It is worth mentioning that during that time, Congo was under the Marxist-Leninist regime, since socialism was noticed as being the main form of government of African countries after their independence. Today, the land has returned to state ownership in charge of the management for the benefit of the people. So, because of this amendment, clashing relationships between state authorities and landowners have been reported and regarding the current situation, this war is far from being over. In fact, both bodies are selling land to the population.

Acquire a piece of land to build decent housing that meets the standards of modernity in Brazzaville demands enormous resources, however it turns out that the cost of living is very high in this first Congolese metropolis. With the economic necessities which tend to satisfy social demands, including the acquisition of cheap land to build personal housing, with or without the complicity of city administrators, landowners sell land anarchically. These sales are made with a slight concern for sanitation and protection facilities required for public utility surfaces. (Ngodi 2008). The conflicts between municipal authorities and landowners are particularly acute (Ziavoula, 1988). the conflict rate per number of land piece sold shows that $58.3 \%$ of observed conflicts affect the rare lands sold by the neighborhood committees, $5.9 \%$ of conflicts affect many lands sold by traditional authorities and lands sold by the administration account for 6.5 of the conflicts.

\section{The Housing Crisis and the Causes of Residential Mobility}

The urbanization of large cities causes many challenges. An urbanization under control not only stimulates the economy but also improves the quality of life. According to the report of the UN-HABITAT (Nzoussi, 2014), most urban residents in Africa southern Sahara live in slums (Matthew, 2007). Lodge population is a challenge that these governments have to cope with in order to ensure their wellbeing. It is the reason why, in Brazzaville public authorities are trying to develop strategies to solve this thorny urban problem.

Residential mobility can be defined as the change in lodgment or residence. In other words, residential mobility is more or less housing instability, that is, the fact that a household changes accommodation. It depends on several factors and also assumes a changing social status of a household (Amadou 2005). The causes of residential mobility in the city of Brazzaville include change of households' social status, lack of basic legal contract between the landlords and tenants, inadequate means to rental fees, housing insufficiency, considerable distance between homes and workplaces, the high cost of living.

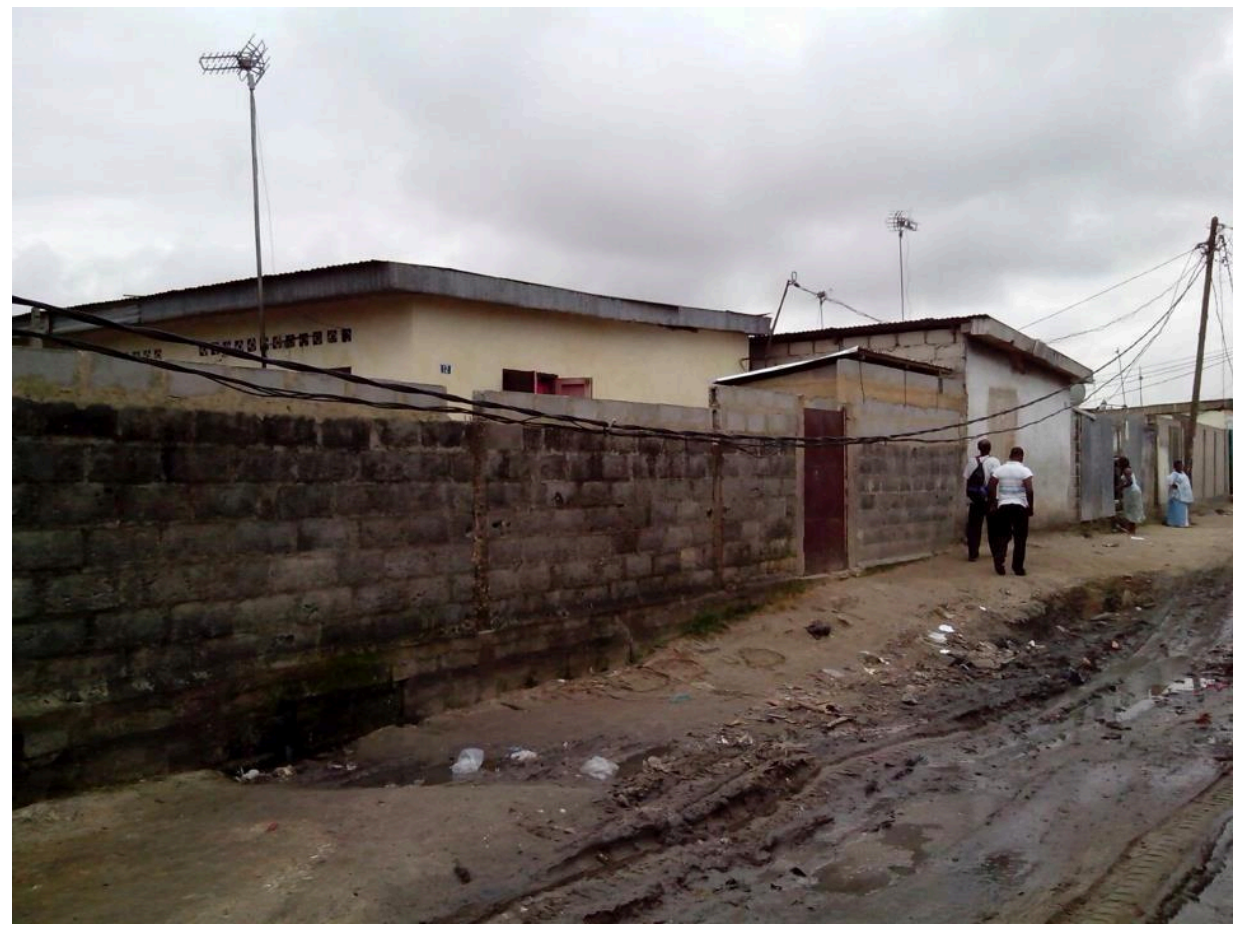

Figure 3. brick house Bacongo (Brazzaville) 
Indeed, the absence of an effective policy on the management and construction of social housing is a serious problem in Brazzaville. We note only $10 \%$ of houses that meet urban standards (Dornier-Apprill and Kouvaouama (1998). The habitat or types of the most popular homes are bare or covered of cinder products. These small houses tin roof open, without glass in the ceiling or just window shutters are the dominant habitat type in all the popular areas (70\% of units) (Same). The brick houses are increasingly visible in Bacongo, a residential neighborhood (Figure 3).

In outlying areas and away, this poor frame and particularly uniform is the only habitat size (Ibid.). Increasing urban population causes a significant decline in life quality. (Nzoussi, 2014).

In Brazzaville, the average prices of housings having 3 rooms range between 50 and 80,000 cfa and 160 USD, it turns out that the minimum salary (the minimum starting professional salary) is 93,000 CFA or 180 USD. As results low income households unable to afford decent housing are best candidates for residential mobility especially towards the peripheral areas with the aim of finding a less expensive housing. The suburbs are marginalized and lack of basic urban facilities, as they are still far from the city and deficient in basic infrastructure and employment (Dureaud et al, 2000).

The lack of a proper legal framework defining the lease between the tenant and the owner as well as the absence of an urban housing policy in Brazzaville are all factors that foster the residential mobility in the city of Brazzaville. Brazzaville is one of the most expensive cities in Africa and things are getting so worse for many people in such an extent that they do not know who to rely on.

\subsection{Indices of Residential Mobility}

Several indicators show the existence of residential mobility in cities of Congo in general and particularly in Brazzaville. Population growth of the city leads to hurried constructions that sometimes do not meet the urbanization standard. In addition, the housing stock in Brazzaville is made up of horizontal lodgments. The spatial extension of the city gets people more and more away from their workplaces. This can be accountable for the fact that the people in charge of to build houses do not have enough resources to build housing on many levels, the scarcity of water and electricity. Note that the multi-level housings not only contribute to an effective management of space, but also requires a lot of resources, water and electricity continuously for proper maintenance. Building a house or an infrastructure or a structure is good, but taking care of is financially and availability demanding.

Residential mobility, voluntary for some households, involuntary for others are very noticeable in Brazzaville. Many families whose incomes depend on the informal sector may have difficulty to afford housings whose prices are not stable because of some dishonest owners. Their formula is 'If you do not want to pay, leave, the house is never uninhabited'. Pay house rent is not easy especially for vulnerable social groups that is why they resort to residential mobility.

As most tenants are working in the informal sector, they face low and fluctuating incomes that do not allow them to be pay regularly houses rent. As a results, for all of them, there is conflicting relationships between landlords and them (Amadou 2005). With a population of over one million people, state workers in the public services are tiny. Therefore most people are taking informal occupations. The informal sector includes standards and specific values with respect to modernity, and in addition these are atypical cultural forms that favour practices and institutions indifferent to the legal and institutional framework (Villers, 1999). Congo Brazzaville, a Very Indebted Poor Country status in relation to which assigned by the Bretton Woods institutions including the IMF and the World Bank, although having abundant mineral resources, is one of those countries where the informal sector grew over the past decade, especially with the arrival of mobile phones that spawned the 'phone booths' which unemployed youth and graduates make a living with. Brazzaville as its capital city escapes way for informal activities.

\subsection{Consequences}

Every family builds its itinerary through the city. Whatever form it might take, family is an essential element of urban life because it is the smallest social unit sounding as a social anchor where any individual learn how to behave properly in the society. (Agier, 1999).

The consequences of residential mobility are visible throughout the city of Brazzaville. However, in developed countries rich people leave the cities because of pollution, high cost of living, traffic congestion and other relevant issues, here in Brazzaville, people move more and more from central areas towards the peripheral areas. In addition, we should mention the forced mobility related to the expropriation of land and housing by state authorities because of public works. As a result, the spatial expansion of peripheral areas is performed haphazardly and without any assistance. As we know, in the cities of southern countries, the populations are installed even before the establishment of urban infrastructures (roads, hospitals, markets schools ...)

The Republic of Congo also called Congo - Brazzaville (to distinguish it from its neighbor, the Democratic Republic of Congo (DRC) and Congo Kinshasa) has experienced for many years 02-digit growth that unfortunately does not benefit to the poor (Ngakoli, 2014). Notwithstanding the commitment made by States in the context of the Millennium Development Goals of reducing poverty by 2015 has not yet yielded successful results. Till today, there are a fair proportion of people living with less than $\$ 1$ a day, (regarded as being the poverty level). The recent report of the 2014 World Bank says that Congo has $50 \%$ of the urban poor against $75 \%$ in rural areas. It ranked 136th out of the 182 HDI (Human Development Index), UNDP (United Nations Development Programme).

Population growth has always been the source of many problems when births are not controlled. It is what is happening today in the city of Brazzaville. Public spaces are swallowed up by a population that is looking for a piece of land in order to escape from the rental restrictions. Land disputes between state authorities, populations and landowners are exasperating. As part of the modernization of the city and especially the incident occurred on March $4^{\text {th }}, 2012$ due to the explosion of ammunition deposits over an area of more than $5 \mathrm{~km} 2$, more than seven million 
families lost their homes. The disaster which cost more than 300 lives has dramatically altered the plan of the city of Brazzaville. Consequently, there have been some lands expropriation in the residential district hosting this military site. In an attempt to improve its image and regain its influence, state authorities are trying to take some measures in order to address the housing problem which is of great importance for Congolese.

Residential mobility exist all over the world, for instance in the USA, Canada, France, China ... But in Congo and especially in the city of Brazzaville, this phenomenon constitutes a serious problem which reduce people's lives quality. Anyway, people have to adapt not only to the city requirements but also to that of globalization.

\section{Conclusion and Recommendations}

In this twenty-first century the housing issue is becoming very crucial in African cities southern Sahara. Food and transportation are also other concerns of Congo Brazzaville raised by the exponential population growth noticed in the city during the recent years. The aim of this article is to scrutinize the phenomenon of residential mobility in Brazzaville which to sum up is due to legal, economic and social problems. Thus, the government need to define a good policy for the construction of social housing as it is done elsewhere. They should favour access for the poor to housings at affordable prices. In addition, a legal framework need to be established to settle disputes between tenant and owners inspiring on the Senegalese model regarding housing prices set by the owners. In fact, a recent survey was conducted Senegal show that most urban households spend more than two thirds of their income in nutrition and housing. Consequently, house prices weigh heavily on ménages. So, they must be set by the government.

\section{Acknowledgement}

I sincerely thank the Chinese government for granting me this PhD scholarship. This is an Opportunity for me not only to get familiarized to the international world, but also to bring my modest contribution in scientific research. I thank also Professor Li Jiang Feng; Head of Department of Land Resource Management for supervising my thesis. My thanks also goes on my relatives, friends and Acquaintances That Constantly brings me their help. This is mainly due to M'passi Marie Viviane Nzoussi My Angel Mitchel and Kidilou Celine.

\section{References}

[1] Agier M., The invention of the city. Suburbs, townships and favelas, Paris, ed conditions of contemporary archives, 1999.

[2] Anglade F. and al, Cities stormed; internal migration policy in Africa No. 31, City of Brazzaville, Paris, Karthala, 26, 1988.

[3] Amadou M. Course migration of urban residents and the housing problem in Niamey UAMN, DEA, 2005.

[4] Dornier-Apprill E.et Kouvaouama A., living in Brazzaville modernity and crisis every day, Paris Karthala, 1999.

[5] Dureaud and al, Metropolis in movements, Paris, Anthropos IRD, 2000.

[6] Matthew M, Habitat for Humanity International in Finance Development, 2007.

[7] Motsara A., Conference Proceedings, 25-28 April 1986 Brazzaville, ORSTOM, 12, 1986.

[8] Ngakoli. E. V. Economic growth and poverty; pro-poor growth? In the republic of Congo in Theoretical Economics Letters (TEL); Vol 4 (6), 473-476 (e-ISSN2162-2086), June 2014

[9] Ngodi E., Management of public spaces in Congo Brazzaville. If parking, condersia, 2008

[10] Nzoussi K H., Economic and social contributions of parkings in Brazzaville, case study of Bacongo total market in International Journal of science and Research(IJSR);Vol 3(7), 384-386(e-ISSN 2319-7074), July 2014

[11] Nzoussi K H., Decentralization, local governance and types of transport in Brazzaville in International Journal of Science and Research (IJSR); Vol 3 (8),147-149 (e-ISSN 2319-7074), August 2014

[12] Vennetier P., what cities in tropical Africa? But problems of rapid urbanization newsletter Geographical Society of Liege, 63- 75, 1990.

[13] Villers G, Informal Sector in Congo Kinshassa, strategies for developing endogenous ie ne, USA, Kinshassa, 35-36, 1999.

[14] Yekoka, F., Urban spatial practices and imbroglio in Brazzaville, analysis of public administration dysfunction of space condersia, 2008.

[15] Ziavoula E.R, The race for the urban space; land conflicts in Brazzaville in African policy No. 31, City of Brazzaville, Paris, Karthala, 1988. 